Egyptian Journal of Rabbit Science, 21 (1): 83- 100(2011)

\title{
EFFECT OF DISTILLERS DRIED GRAINS WITH SOLUBLES (DDGS) SUPPLEMENTED WITH OR WITHOUT ENZYME ON THE PERFORMANCE OF GROWING RABBITS
}

\author{
M. A. A. Hussein and A.EL M. I . EL Desoky \\ Animal Production Research, Institute Agriculture Research Center, \\ Ministry of Agriculture, Dokki, Giza, Egypt.
}

A factorial experiment $(4 \times 2)$ was carried out including four levels of corn distiller dried grain with solubles (DDGS) ( 0,16,22 and 28\%) and two levels of supplemental enzyme (0.0 and $0.5 \mathrm{gm} /$ Zylam $\mathrm{kg}$ diet). A total number of $96 \mathrm{New}$ Zealand( NZW) rabbits at 5 wks old were weighed and randomly distributed into the 8 treatment groups rabbits, each) in three replicates (4rabbits, each).Growth performance, economic efficiency, apparent digestibility and carcass traits as well as blood plasma constituents were studied during the growing period (5-14 weeks).

Results show that no significant differences in live body weight ( $L B W$ ), body weight gain ( $B W G$ ) and feed intake ( FI) were observed by different levels of inclusion DDGS, enzyme supplementation or the interaction between their in rabbit diets except BWG during 12-14 weeks of age, which it was significantly $(P<0.05)$ improved by feeding different levels of DDGS . Inclusion of 22 and $28 \%$ DDGS in growing rabbit diets had significantly improved feed conversion ratio( FCR), protein efficiency ratio( PER) and performance index( PI) as compared with the control during the whole experimental period. However, increasing DDGS to 22 or $28 \%$ in growing rabbit diets significantly decreased energy efficiency utilization (EEU) as compared with the control during overall experimental period. Economic efficiency (EEF) \% were affected by DDGS inclusion during the whole experiment period, group of rabbits fed diets containing 28\% DDGS exhibited the best EEF value as compared to control diets. All digestibility coefficient of nutrients and nutritive value were insignificantly improved by DDGS, enzyme supplementation and their interaction. Eviscerated carcass, total edible parts and abdominal fat percentages were insignificantly higher by increasing DDGS and enzyme addition levels as compared to control diets during the growth period. The DDGS had no significant effect on plasma total protein, total cholesterol, aspartate aminotransferase (AST),alanine aminotransferase (ALT) and creatinine, while, it is had significantly $(p<0.01)$ decreasing total lipids as compared to the control. 
However, enzyme addition had not significant effects on all plasma constituents except of total lipids which significantly increased by enzyme addition only as compared to the control .

In conclusion, the present results show that DDGS can be used successfully in growing rabbit feeding effectively and economically up to $28 \%$ without adverse effect on growth performance. Carcass traits, blood constituents and animal health in general.

Keywords :DDGS, rabbit, growth performance, digestibility coefficients, carcass traits, blood parameters.

In recent years, the ethanol production as a partial substitute of petrol has rapidly increased and further increases are expected in the future (Windhorst, 2007). Ethanol is currently produced at a commercial scale via enzymatic breakdown of starch and yeast controlled fermentation of glucose into ethanol. This production is mainly based on corn, whereas, wheat or barley are used in ethanol plants. Distillers dried grains with solubles (DDGS) is the primary resulting by-product of this production. Mainly of these by-products were used in ruminant feeds (Shurson, 2008), and were become available for non ruminants according to the increased availabilities (Batal and Dale, 2003 and Noll et al., 2007).

Recently many investigators used DDGS in feeding some of the farm animals, like horse (Hill,2002), beef (Martin et al.,2007 and MacDonald et al.,2007), dairy cattle (Kleinschmit et al.,2006), small ruminant (Archibeque et al.,2008), broilers (Wang et al.,2007) and Shalash et al., 2009), laying hens (Lumpkins et al.,2004; Thacker ,2007 and Shalash et al., 2010), turkey hens (Robertson , 2003 ), laying duck (Awad et al.,2011a) and growing duckling ( Awad et al., 2011b).

In Egypt, there is need to seek for more untraditional animal feed resources to compensate the shortage of animal feeds. Rabbits have a substantial role in making use of a large amount of agricultural manufacture by-products and indeed the economics of the production systems depend mainly up on the efficient use of all the component resources. One of these by-products is dried distillers grains with solubles, which still not used at large scale in Egypt as a feed ingredient in farm animals rations.

Zylam 500 is a mixture enzymes processed from Baciluss subtilis, and produced by a micro filtration advanced fermentation technique. Zylam 500 is a highly efficacious Zylanase in degrading both soluble and insoluble arabino-Zylans, the most important anti-nutritional factor in cereals and ceaeal by products used in animal feed so as to improve the utilization of nutrients, animal uniformity and animal performance, increase proportional usage of cereal by-products in formulating animal feed to reduce feed cost. 
Therefore, the current study aimed to investigate the effects of DDGS inclusion in growing rabbit diets with or without enzyme supplementation on the growth performance, digestibility coefficients, carcass traits and some blood constituents, as well as, the economic efficiency during the growing period.

\section{MATERIALS AND METHODS}

This study was carried out in a private rabbit farm at Dekkrns, Dakahlia Governorate, Egypt. It was started in September 2010 and terminated at November of the same year.

A factorial design experiment $(4 \times 2)$ was performed including four levels of DDGS ( 0, 16, 22 and 28\%) and two levels of Zylam supplementation ( 0.0 or $0.5 \mathrm{gm} / \mathrm{kg}$ diet) as recommended Khyrat El- Nile Company, Naser City, Egypt. Ninety six growing NZW rabbits 5 weeks of age were nearly equal in average live weight distributed into eight experimental groups (12 rabbits each group). Each treatment was consisted of 3 replicates of 4 rabbits each.. Each group of rabbits was fed on one of the eight diets which contained corn DDGS $(0,16,22$ or $28 \%$ ) with or without $(0.0$ or $0.50 \mathrm{~g}$ Zylam / kg diet) enzyme addition (Table 1). All experimental diets were nearly isocaloric and isonutrogenous and cover the requirements of growing rabbits as recommended by NRC (1977). Rabbits were housed in galvanized cages in well-ventilated pens. Each cage have a stainless steel nipple for drinking. Fresh water and pelleted diets were offered ad libitum throughout the experimental period from 5 to 14 wks of age. Rabbits were reared under similar hygienic, environmental and managerial conditions

Live body weight and feed intake of rabbits were recorded at $5,8,11$ and 14 weeks of age. While, body weight gain and feed conversion ratio were calculated at 5-8, 9-11, 12-14 and 5-14 wks of age. Protein efficiency ratio,energy efficiency utilization and performance index were also calculated for the whole experimental period. The PER was calculated as weight gain (g) / crude protein consumed (g), EEU was calculated as digestible energy consumed ( Kcal ) / weight gain (g), whereas, PI was calculated as live weight $(\mathrm{Kg}) /$ feed conversion x 100 according to North (1981) for the certain periods . The economic efficiency was calculated at the periods of 5-14 weeks of age as follows: Economical efficiency $=$ ( price of one $\mathrm{kg}$ live weight - feed cost $/ \mathrm{kg}$ gain / feed cost $/ \mathrm{kg}$ gain) $\mathrm{x} 100$. The selling price of one $\mathrm{kg}$ weight was considered to be 18.0 L.E.

At the end of experiment, eight digestibility trails were conducted according to Fekete and Gippert (1982) by using three rabbits from each experimental group (one from each replicate) were housed individually in metabolic cages that permit to collect faces and urine separately. The trial lasted for 7 days as a preliminary period followed by 5 days as a collection period to 
Table 1. Composition and calculated analysis of the experimental diets .

\begin{tabular}{|c|c|c|c|c|c|c|c|c|}
\hline \multirow[b]{2}{*}{ Ingredients } & \multicolumn{8}{|c|}{ Treatment groups } \\
\hline & 1 & 2 & 3 & 4 & 5 & 6 & 7 & 8 \\
\hline Yellow corn & 15.00 & 11.00 & 7.00 & 6.00 & 15.00 & 11.00 & 7.00 & 6.00 \\
\hline DDGS ${ }^{1}$ & 0.00 & 16.00 & 22.00 & 28.00 & 0.00 & 16.00 & 22.00 & 28.00 \\
\hline Barley & 20.00 & 20.00 & 20.00 & 20.00 & 20.00 & 20.00 & 20.00 & 20.00 \\
\hline Soybean meal(44\%) & 15.00 & 8.00 & 5.00 & 3.00 & 15.00 & 8.00 & 5.00 & 3.00 \\
\hline Wheat bran & 17.00 & 12.00 & 13.00 & 10.00 & 17.00 & 12.00 & 13.00 & 10.00 \\
\hline Egyptian clover hay & 30.00 & 30.00 & 30.00 & 30.00 & 30.00 & 30.00 & 30.00 & 30.00 \\
\hline Di-calcium P. & 1.20 & 1.20 & 1.20 & 1.20 & 1.20 & 1.20 & 1.20 & 1.20 \\
\hline Lime stone & 1.00 & 1.00 & 1.00 & 1.00 & 1.00 & 1.00 & 1.00 & 1.00 \\
\hline Salt & 0.50 & 0.50 & 0.50 & 0.50 & 0.50 & 0.50 & 0.50 & 0.50 \\
\hline Premix ${ }^{2}$ & 0.30 & 0.30 & 0.30 & 0.30 & 0.30 & 0.30 & 0.30 & 0.30 \\
\hline Total & 1000 & 100 & 100 & 100 & 100 & 100 & 100 & 100 \\
\hline \multicolumn{5}{|c|}{ Zylam $(500 \mathrm{gm} / \text { ton })^{3}$} & $x \times$ & $x \times$ & $x \times$ & $x \times$ \\
\hline \multicolumn{6}{|c|}{ Calculated analysis ( air dry basis $)^{4}:$} & & & \\
\hline DE,kcal/kg & 2550 & 2560 & 2550 & 2560 & 2550 & 2560 & 2550 & 2560 \\
\hline Crude protein $\%$ & 17.12 & 17.16 & 17.23 & 17.12 & 17.12 & 17.16 & 17.23 & 17.12 \\
\hline Crude fiber\% & 12.48 & 12.64 & 12.93 & 12.92 & 12.48 & 12.64 & 12.93 & 12.92 \\
\hline Ether extract\% & 2.56 & 3.52 & 3.93 & 4.28 & 2.56 & 3.52 & 3.93 & 4.28 \\
\hline Calcium\% & 1.02 & 1.08 & 1.00 & 1.00 & 1.02 & 1.08 & 1.00 & 1.00 \\
\hline Total P\% & 0.74 & 0.74 & 0.76 & 0.75 & 0.74 & 0.74 & 0.76 & 0.75 \\
\hline Lysine\% & 0.86 & 0.72 & 0.67 & 0.63 & 0.86 & 0.72 & 0.67 & 0.63 \\
\hline Methionine\% & 0.25 & 0.27 & 0.28 & 0.29 & 0.25 & 0.27 & 0.28 & 0.29 \\
\hline Meth+ cys\% & 0.52 & 0.53 & 0.54 & 0.55 & 0.52 & 0.53 & 0.54 & 0.55 \\
\hline \multicolumn{9}{|c|}{ Determined analysis (dry matter basis) : } \\
\hline OM\% & 88.80 & 88.82 & 88.76 & 88.78 & 88.80 & 88.82 & 88.76 & 88.78 \\
\hline $\mathrm{CP} \%$ & 19.26 & 19.23 & 19.20 & 19.22 & 19.26 & 19.23 & 19.20 & 19.22 \\
\hline $\mathrm{CF} \%$ & 14.08 & 14.19 & 14.24 & 14.14 & 14.08 & 14.19 & 14.24 & 14.14 \\
\hline EE\% & 3.60 & 3.62 & 3.64 & 3.62 & 3.60 & 3.62 & 3.64 & 3.62 \\
\hline NFE\% & 45.04 & 45.26 & 45.33 & 45.30 & 45.04 & 45.26 & 45.33 & 45.30 \\
\hline Ash\% & 18.02 & 17.70 & 17.59 & 17.72 & 18.02 & 17.70 & 17.59 & 17.72 \\
\hline DE kcal/kg & 2601 & 2612 & 2623 & 2612 & 2602 & 2612 & 2627 & 2614 \\
\hline Price (L.E $/ \mathrm{kg})^{5}$ & 200.0 & 190.8 & 185.5 & 183.3 & 204.0 & 194.8 & 189.5 & 187.5 \\
\hline
\end{tabular}

1- DDGS = Corn distillers dried grains with solubles (3035,DE. 26.3\% ,CP. 9.0\%,EE . $8.1 \%$, CF . $0.14 \%, \mathrm{Ca} .0 .73 \%$, Total P.)

2- Each $1 \mathrm{~kg}$ of the Vit and Min. contains: Vitamin A 2 MIU, Vit. $\mathrm{D}_{3} 150000 \mathrm{IU}$, Vit E $8.33 \mathrm{~g}$, Vit. K 0.33 g, Vit $B_{1} 1$ g, Vit.B 1.09 g, Vit. $B_{6} 0.33$ g, Vit. B 8.33 g, Vit. B 12.7 mg, Pantothenic acid $3.33 \mathrm{~g}$, Folic acid 0.83 g, Biotin $33 \mathrm{mg}$, Choline chloride $20 \mathrm{~g}, \mathrm{Mg} .66 .79 \mathrm{~g}$, Zn. $11.79 \mathrm{~g}$, Fe. $12.5 \mathrm{~g}, \mathrm{Cu} .0 .5 \mathrm{~g}, \mathrm{I} .0 .3 \mathrm{~g}$, Se. $16.6 \mathrm{mg}$, Co. $1.33 \mathrm{mg}$. and carrier $\mathrm{CaCO}_{3}$ to $1000 \mathrm{~g}$.

3- Each $1 \mathrm{~g}$ of Zylam (500) contains: $\beta$.Xylanase $(1,260 \mathrm{U} / \mathrm{g}), \alpha$-amylase $8,000 \mathrm{U} / \mathrm{g}$ carrier wheat flour. 4- According to NRC ( 1977 )

5-Price of one $\mathrm{kg}(\mathrm{LE})$ at time of experiment for different ingredients : Yellow corn ,1.90; Soybeen meal, 3.00 ; DDGS, 1. 60 ; Barley, 1.80 ; Wheat bran, 1.60 ; Egyptian clover hay, 1.25 ; Di - calcium, 4.00 ; limestone, 0.10 ; Salt , 0.25 ; Vit \& Min , 9.00 ; Meth , 24,00 ; Lys, 13, 00 and Zylam ( 500 ), 90.00 . 
quantify the consumed feed and faeces output .Routine chemical analysis of samples of feed and faeces was performed according to A.O.A.C (1995). Apparent digestibility coefficients and nutritive value (TDN) were calculated according to the formula described by Cheeke et al. (1982).

At the end of experimental period (14 wks of age), three rabbits from each treatment group (one from each replicate) were randomly selected and slaughtered. Rabbits were fasted for 18 hours before slaughtering, then were weighed individually as a pre-slaughter weight. Data of carcass traits (including eviscerated carcass, head, liver, heart and edible parts as well as abdominal fat) were calculated as $\%$ of pre-slaughter weight. At slaughtering time , blood samples from each rabbit were collected in heparinized test tubes and centrifuged at $3500 \mathrm{rpm}$ for 15 minutes to obtain blood plasma .Plasma were assigned for determination of total protein (Peters, 1968), total cholesterol ( Ellefson and Caraway, 1976 ), total lipids (Bucolo and David, 1973), transaminase enzymes activities ALT and AST (Reitman and Frankel,1957) and createnine by using commercial kits.

Data of the experiment were statistically analyzed using the General linear model of SAS (2004). In this study, the model used was 4 x 2 factorial design. Considering the DDGS and enzyme addition level as the main effects, as follows: Yijk $=\mu+\mathrm{Ti}+\mathrm{Rj}+(\mathrm{TR}) \mathrm{ij}+\mathrm{eijk}$

Where : Yijk $=$ An observation ; $\mu=$ Overall mean ; $\mathrm{T}=$ Effect of DDGS levels ; $\mathrm{i}=(1,2,3$ and 4$) ; \mathrm{R}=$ Effect of enzyme addition levels ; $\mathrm{j}=(1$ and $2) ; \quad T R=E f f e c t$ of interaction between DDGS and enzyme addition levels ; and eijk $=$ Experimental random error.

Differences among treatment means were estimated by Duncan's multiple range test (Duncan, 1955).

\section{RESULTS AND DISCUSSION}

\section{Growth performance}

Results in Table (2) showed that no significant effect was detected among NZW rabbits fed on diets contained different levels of both DDGS levels or enzyme supplementation and their interaction on their live body weight (LBW) and Body weight gain (BWG) during all experimental periods, except body weight gain during 12-14 wks, which it was significantly $(\mathrm{P}<0.05)$ improved by feeding different levels of DDGS only as compared to the control (Table 2).

These results were confirmed with Gaber et al. (2008) who found that feeding NZW rabbits diets contained DDGS up to $20 \%$ DDGS with or without enzyme addition had no significant effects on live body weight and body weight gain from 8-14 wks of age. Also, Lumpkins et al. (2004) reported that feeding broiler diets contained 0-18\% DDGS had no 
Table 2. Effect of dietary DDGS and enzyme supplementation levels and their interaction on live body weight and body weight gain at different ages of NZW rabbits.

\begin{tabular}{|c|c|c|c|c|c|c|c|c|c|}
\hline \multirow{2}{*}{\multicolumn{2}{|c|}{$\begin{array}{l}\text { Treatment } \\
\text { groups }\end{array}$}} & \multicolumn{4}{|c|}{ LBW (g) } & \multicolumn{4}{|c|}{ BWG (g) } \\
\hline & & $\begin{array}{c}5 \\
\text { wk }\end{array}$ & $\begin{array}{c}8 \\
\text { wk }\end{array}$ & $\begin{array}{l}11 \\
\text { wk }\end{array}$ & $\begin{array}{c}14 \\
\text { wk }\end{array}$ & $\begin{array}{c}5-8 \\
\text { wks }\end{array}$ & $\begin{array}{r}9-11 \\
\text { wks }\end{array}$ & $\begin{array}{c}12-14 \\
\text { wks }\end{array}$ & $\begin{array}{l}\text { 5-14 } \\
\text { wks }\end{array}$ \\
\hline \multicolumn{10}{|c|}{ DDGS level \% } \\
\hline \multicolumn{2}{|l|}{0.0} & 615.0 & 1157.0 & 1780.8 & 2244.9 & 25.80 & 29.70 & $22.08^{b}$ & 25.88 \\
\hline \multicolumn{2}{|l|}{16.0} & 605.8 & 1119.8 & 1682.5 & 2308.8 & 24.48 & 26.80 & $29.82^{a}$ & 27.07 \\
\hline \multicolumn{2}{|l|}{22.0} & 625.0 & 1113.2 & 1762.8 & 2402.0 & 23.25 & 30.93 & $30.45^{\mathrm{a}}$ & 28.20 \\
\hline \multicolumn{2}{|l|}{28.0} & 613.7 & 1145.8 & 1743.9 & 2338.9 & 25.35 & 28.48 & $28.33^{\mathrm{a}}$ & 27.37 \\
\hline \multicolumn{2}{|c|}{ SEM } & 10.31 & 25.37 & 53.61 & 55.95 & 1.19 & 1.89 & 2.08 & 0.84 \\
\hline \multirow{2}{*}{\multicolumn{2}{|c|}{ Significance }} & NS & NS & NS & NS & NS & NS & $*$ & NS \\
\hline \multicolumn{9}{|c|}{ Enzyme level $(\mathrm{g} / \mathrm{kg})$} & \\
\hline \multicolumn{2}{|l|}{0.0} & 615.6 & 1133.6 & 1740.7 & 2319.2 & 24.67 & 28.92 & 27.54 & 27.05 \\
\hline \multicolumn{2}{|l|}{0.5} & 614.2 & 1134.8 & 1744.3 & 2328.1 & 24.78 & 29.04 & 27.80 & 27.21 \\
\hline \multicolumn{2}{|c|}{ SEM } & 7.29 & 17.94 & 37.91 & 39.56 & 0.84 & 1.34 & 1.47 & 0.59 \\
\hline \multicolumn{2}{|c|}{ Significance } & NS & NS & NS & NS & NS & NS & NS & NS \\
\hline \multicolumn{10}{|c|}{ Interactions } \\
\hline \multicolumn{10}{|c|}{ DDGS EN } \\
\hline \multirow{2}{*}{0.0} & $\mathbf{0 . 0}$ & 610.0 & 1185.0 & 1850.0 & 2335.8 & 27.37 & 31.67 & 23.13 & 27.40 \\
\hline & 0.5 & 620.0 & 1129.2 & 1711.7 & 2153.9 & 24.23 & 27.73 & 21.03 & 24.37 \\
\hline \multirow{2}{*}{16.0} & 0.0 & 610.0 & 1129.2 & 1706.1 & 2266.4 & 24.73 & 27.47 & 26.67 & 26.33 \\
\hline & 0.5 & 601.7 & 1110.5 & 1658.9 & 2351.1 & 24.23 & 26.13 & 32.97 & 27.80 \\
\hline \multirow{2}{*}{22.0} & 0.0 & 625.0 & 1098.6 & 1764.5 & 2365.6 & 22.53 & 31.73 & 28.63 & 27.63 \\
\hline & 0.5 & 625.0 & 1127.8 & 1761.1 & 2438.3 & 23.97 & 30.13 & 32.27 & 28.77 \\
\hline \multirow{2}{*}{28.0} & 0.0 & 617.5 & 1170.0 & 1642.2 & 2308.9 & 24.03 & 24.80 & 31.73 & 26.83 \\
\hline & 0.5 & 610.0 & 1121.7 & 1845.5 & 2368.9 & 26.67 & 32.17 & 24.93 & 27.90 \\
\hline \multicolumn{2}{|c|}{ SEM } & 14.58 & 35.87 & 75.82 & 79.13 & 1.68 & 2.68 & 2.95 & 1.18 \\
\hline \multicolumn{2}{|c|}{ Significance } & NS & NS & NS & NS & NS & NS & NS & NS \\
\hline
\end{tabular}

DDGS $=$ Distillers dried grains with solubles, $\quad$ SEM $=$ Stander error mean, Wks $=$ Weeks $\mathrm{a}, \mathrm{b}$ :Means in the same column bearing different superscript are significantly different $(\mathrm{P} \leq 0.05)$. NS $=$ Not significant $\quad *=$ Significant at $(\mathrm{P}<0.05)$

significant differences in their performance. Recently, Noll and Brannon (2006) with turkeys fed 20\% DDGS and Awad et al. (2011 b) with Domyati ducklings came to the same conclusions.

Data of Table (3) showed that feed intake was not significantly affected by DDGS levels and enzyme supplementation and their interaction during all experimental periods. It could be noticed that FI of rabbits fed diet contained 
Table 3 : Effect of dietary DDGS and enzyme supplementation levels and their interaction on daily feed intake and feed conversion ratio of NZW rabbits during the experimental periods (5-14 weeks of age)

\begin{tabular}{|c|c|c|c|c|c|c|c|c|c|}
\hline \multirow{2}{*}{\multicolumn{2}{|c|}{$\begin{array}{l}\text { Treatment } \\
\text { groups }\end{array}$}} & \multicolumn{4}{|c|}{ FI $(g / d)$} & \multicolumn{4}{|c|}{ FCR } \\
\hline & & $\begin{array}{l}5-8 \\
\text { wks }\end{array}$ & $\begin{array}{l}9-11 \\
\text { wks }\end{array}$ & $\begin{array}{c}12-14 \\
\text { wks }\end{array}$ & $\begin{array}{l}5-14 \\
\text { wks }\end{array}$ & $\begin{array}{l}5-8 \\
\text { wks }\end{array}$ & $\begin{array}{l}9-11 \\
\text { wks }\end{array}$ & $\begin{array}{c}12-14 \\
\text { wks }\end{array}$ & $\begin{array}{l}5-14 \\
\text { wks }\end{array}$ \\
\hline \multicolumn{10}{|c|}{ DDGS level \% } \\
\hline \multirow{5}{*}{\multicolumn{2}{|c|}{$\begin{array}{l}0.0 \\
16.0 \\
22.0 \\
28.0 \\
\text { SEM } \\
\end{array}$}} & 81.73 & 128.45 & 153.62 & 121.28 & $3.18^{\mathrm{a}}$ & $4.35^{b}$ & $7.06^{\mathrm{a}}$ & $4.71^{\mathrm{a}}$ \\
\hline & & 77.38 & 129.57 & 165.15 & 124.03 & $3.16^{\mathrm{a}}$ & $4.86^{\mathrm{a}}$ & $5.65^{b}$ & $4.59^{\mathbf{a b}}$ \\
\hline & & 73.00 & 133.72 & 167.95 & 124.90 & $3.15^{\mathrm{a}}$ & $4.33^{\mathbf{b}}$ & $5.57^{\mathbf{b}}$ & $4.43^{b}$ \\
\hline & & 69.78 & 133.18 & 162.97 & 121.95 & $2.75^{b}$ & $4.76^{a b}$ & $5.87^{\mathbf{b}}$ & $4.45^{b}$ \\
\hline & & 3.20 & 7.39 & 8.76 & 3.44 & 0.02 & 0.16 & 0.19 & 0.06 \\
\hline \multicolumn{2}{|l|}{ Sig. } & NS & NS & NS & NS & * & * & *** & *** \\
\hline \multicolumn{10}{|c|}{ Enzyme level $(\mathrm{g} / \mathrm{kg})$} \\
\hline \multirow{3}{*}{\multicolumn{2}{|c|}{$\begin{array}{l}0.0 \\
0.5 \\
\text { SEM } \\
\end{array}$}} & 74.17 & 125.56 & 157.46 & 119.07 & $3.02^{b}$ & $4.41^{b}$ & $5.84^{b}$ & $4.41^{\mathbf{b}}$ \\
\hline & & 76.78 & 136.90 & 167.38 & 127.02 & $3.11^{\mathrm{a}}$ & $4.74^{\mathrm{a}}$ & $6.24^{\mathrm{a}}$ & $4.69^{a}$ \\
\hline & & 2.27 & 5.23 & 6.19 & 2.43 & 0.02 & 0.11 & 0.14 & 0.04 \\
\hline \multirow{2}{*}{\multicolumn{10}{|c|}{\begin{tabular}{l|l} 
Sig. & NS \\
Interactions
\end{tabular}}} \\
\hline & & & & & & & & & \\
\hline \multicolumn{10}{|c|}{\begin{tabular}{|l|l|} 
DDGS & EN \\
\end{tabular}} \\
\hline \multirow{2}{*}{0.0} & 0.0 & 80.13 & 127.77 & 146.63 & 118.20 & 2.93 & 4.03 & 6.49 & 4.31 \\
\hline & 0.5 & 83.33 & 129.13 & 160.60 & 124.37 & 3.44 & 4.66 & 7.63 & 5.11 \\
\hline \multirow{2}{*}{16.0} & 0.0 & 78.57 & 121.27 & 157.80 & 119.23 & 3.18 & 4.44 & 5.99 & 4.53 \\
\hline & 0.5 & 76.20 & 137.87 & 172.50 & 128.83 & 3.15 & 5.28 & 5.31 & 4.66 \\
\hline \multirow{2}{*}{22.0} & 0.0 & 71.90 & 132.27 & 166.67 & 123.63 & 3.20 & 4.18 & 5.88 & 4.49 \\
\hline & 0.5 & 74.10 & 135.17 & 169.23 & 126.17 & 3.10 & 4.48 & 5.27 & 4.38 \\
\hline \multirow{2}{*}{28.0} & 0.0 & 66.07 & 120.93 & 15873 & 115.20 & 2.75 & 5.00 & 5.00 & 4.29 \\
\hline & 0.5 & 73.50 & 145.43 & 167.20 & 128.70 & 2.76 & 4.52 & 6.74 & 4.61 \\
\hline \multicolumn{2}{|c|}{ SEM } & 4.53 & 10.46 & 12.39 & 4.87 & 0.03 & 0.22 & 0.27 & 0.08 \\
\hline \multicolumn{2}{|l|}{ Sig. } & NS & NS & NS & NS & $* *$ & $*$ & $* *$ & $* *$ \\
\hline
\end{tabular}

DDGS = distillers dried grains with solubles, $\quad$ SEM $=$ Stander error mean, Wks $=$ Weeks $a, b$ :Means in the same column bearing different superscript are significantly different $(\mathrm{P} \leq 0.05)$. $*$ = Significant at $(0.05) . \quad * *=$ Significant at $(0.01) . \quad$ NS $=$ Not significant

DDGS with or without enzyme supplementation was nearly similar values during the whole experimental period (5-14wks). These results are in agreement with those reported by Gaber et al. (2008) who found that daily feed intake had no significant effects by feeding diets contained DDGS up to $20 \%$ with or without enzyme addition for growing NZW rabbits. Wang et al. (2007) who found that feed intake did not differ significantly for birds fed diet contained 15\% DDGS as compared with those fed diet without DDGS . Similarly, Lumpkins et al. (2004) reported that no significant differences in feed intake were observed by feeding 6-18\% DDGS in broiler diets. Also, 
Awad et al. (2011b) found that no significant effects on feed consumption of Domyati ducklings by feeding 18\% DDGS diet during the growing period.

Values of feed conversion ratio (FCR) of rabbits were significantly affected $(\mathrm{P}<0.05$ or $\mathrm{P}<0.01)$ due to DDGS, enzyme addition and their interaction during all the experimental periods (Table 3). FCR values were significantly $(\mathrm{P}<0.05$ or $\mathrm{P}<0.01)$ improved by feeding diets contained 22 and $28 \%$ DDGS as compared with those fed control diet during the whole experimental period, whereas, it were significantly decreased by enzyme supplementation. The best value of FCR was occurred by feeding diet contained 28\% DDGS without enzyme addition during the whole experimental period (5-14 wks). In this respect, Gaber et al. (2008) who found that feed conversion ratio had no significant effects by feeding diets contained DDGS up to $20 \%$ with or without enzyme addition of NZW rabbits at 6-14 wks of age. Wang et al. (2007) reported that feed conversion ratio did not differ significantly for broiler fed diets contained 15 or $30 \%$ DDGS than those fed diets without DDGS during 0-49 d of age. Also, Awad et al. (2011 b) reported that no significant differences in feed conversion were observed for ducklings by feeding DDGS up to $18 \%$ at growing period.

\section{Protein efficiency ratio (PER):}

Results of Table (4) show that the PER values were significantly $(\mathrm{P}<0.05$ or $\mathrm{P}<0.01)$ affected by different levels of DDGS, enzyme addition and their interaction. PER values were significantly $(\mathrm{P}<0.05)$ improved by feeding 22 and $28 \%$ DDGS diet by about 6.40 and $5.60 \%$, respectively as compared with the control diet during the whole experimental period (5-14 wks). PER value was significantly $(\mathrm{P}<0.01)$ decreased by enzyme addition by about $6.01 \%$ as compared to the control during the whole experimental period (5-14 wks). The interaction between DDGS level and enzyme addition resulted in higher value of PER by feeding $28 \%$ DDGS diet without enzyme addition during the whole experimental period. These results are in contrast with those obtained by Gaber et al. (2008) who reported that varying DDGS diets with or without enzyme addition did not affect protein efficiency ratio (PER) of the NZW rabbits.

\section{Efficiency of energy utilization ( EEU ):}

The efficiency of energy utilization (EEU) values were significantly ( $\mathrm{P}<0.05$ or $\mathrm{P}<0.01$ ) affected by feeding different levels of DDGS, enzyme addition and their interaction (Table 4) during all the experimental periods. EEU values were significantly $(\mathrm{P}<0.05)$ decreased by feeding $22 \%$ DDGS only, whereas, it were no significantly affected by feeding diet contained 16 and $28 \%$ DDGS diet as compared to those fed the control diet during the whole experimental period (5-14wks). EEU values were significantly 
increased by enzyme addition by about $6.40 \%$ as compared to the control at the whole experimental period. The interaction between DDGS level and enzyme supplementation had a higher value of EEU by feeding the control diet with enzyme supplementation during the whole experimental period. These results are in contrast with those obtained by Gaber et al. (2008) who reported that varying DDGS diets $(10,15$ and $20 \%)$ with or without enzyme addition did not affect energy efficiency utilization (EEU) of the NZW rabbits at 8- 14 wks of age.

\section{Performance index ( PI ):}

The performance index $(\mathrm{PI})$ values were significantly( $\mathrm{P}<0.05$ or $\mathrm{P}<0.01)$ affected by feeding different DDGS levels and the interaction between DDGS and enzyme addition while PI values were not significantly affected by enzyme supplementation during experimental periods (Table 4). PI value was significantly $(\mathrm{P}<0.05)$ increased by feeding $22 \%$ DDGS by about $12.71(\%)$ as compared to the control. On the other hand, PI values were significantly $(\mathrm{P}<0.05)$ increased by 4.61 and $9.28 \%$ by feeding diet contained 16 and $28 \%$ DDGS, respectively as compared to those fed the control diet during the whole experimental period (5-14wks). PI values were insignificantly decreased by feeding enzyme addition as compared to the control during the whole experimental period. These results are in agreement with those obtained by Gaber et al. (2008) who reported that rabbits fed diet contained $0.5 \mathrm{~g} / \mathrm{kg}$ enzyme addition had no significant effects on performance index (PI) at the growing period. On the other hand, these results are in contrast with those obtained by Gaber et al. (2008) who reported that rabbits fed diet contained 10 , 15 and $20 \%$ DDGS had no significant effects on performance index (PI) at the growing period.

\section{Economic efficiency $(\%)$ :}

Results of Table (4) showed that the differences in the economical efficiency values due to the DDGS Level in the diet were significant $(\mathrm{P} \leq 0.05)$ Throughout the whole experimental period (5-14 weeks) where the groups fed diet containing $28 \%, 16 \%$ and $22 \%$ had better values of economical efficiency by about 14.7, 12.3 and $3.5(\%)$ than the control group, respectively.

The enzyme supplementation to the experimental diets was insignificantly decreased the economic efficiency by $4.2 \%$ than the control group (unsupplemented). The effect of interaction between DDGS levels and enzyme supplementation was significant at the whole experiment (514 weeks of age). It is clear that rabbits fed diet containing 16\% DDGS without enzyme supplementation recorded the highest economical efficiency $(114 \%)$. 


\section{Apparent digestibility and nutritive values}

Percentages of digestion coefficients of DM, OM, CP, EE, CF , NFE and nutritive value as total digestible nutrients (TDN) are illustrated in Table 5. It is clear that no significant effects were found in all digestibility coefficients and nutritive value due to feeding diets contained different levels of DDGS ,enzyme supplementation and their interaction. All digestibility coefficient of nutrients were insignificantly improved by feeding diet contained different DDGS levels as compared to control. These results may be due to DDGS from the alcohol beverage industry is a valuable source of water-soluble vitamins and minerals (Couch et al., 1970; Jensen, 1981 and Waldroup et al., 1981), which affect feed metabolism . Also, DDGS is high in available nutrients, particularly phosphorus

In this respect, Gaber et al. (2008) found that feeding diet contained DDGS from 0 - $20 \%$ had no significant effects on all digestibility coefficient of nutrients except of OM which decreased by $20 \%$ DDGS of growing rabbits at 14 wks of age Our results agree with Shalash et al. (2010) who reported that digestibility coefficient values of crude protein, crude fiber, ether extract and nitrogen free extract were not significantly affected by DDGS levels (0-20\%)in laying hen diets. Also, Awad et al. (2011b) reported that feeding diet contained $0-18 \%$ DDGS had no significant effect on all digestibility coefficient of nutrients of Domyati duckling at 10 wks of age.

\section{Carcass traits :}

Results of Table (6) show the effect of different levels of DDGS, enzyme supplementation and their interaction in the diets on some carcass traits (expressed as percentages of fasted LBW) of NZW rabbits at 14 wks of age . Eviscerated carcass, total edible parts and abdominal fat percentages were insignificantly higher by feeding 22 and $28 \%$ DDGS diets as compared to the control diet. Enzyme addition resulted in high relative weights of eviscerated carcass and total edible parts as compared to the control without significant differences among them. The interaction between DDGS level and enzyme addition resulted in heavy eviscerated carcass and total edible parts by feeding 22 and $28 \%$ DDGS diets with enzyme addition $(0.5 \mathrm{~g} / \mathrm{kg})$.

Similar results were found by Gaber et al. (2008) they reported that all relative weights of dressing carcass and total edible parts were not differed significantly by feeding 0-20\% DDGS diets of NZW rabbits during growing period. Wang et al. (2007) reported that birds fed diets contained 15 or $20 \%$ DDGS on a constant basis did not differ significantly in dressing percentage and carcass composition as compared to those fed the no DDGS diet . Lumpkins et al. (2004) reported that carcass yield was not significantly affected by feeding diets contained 6,12 , or $18 \%$ DDGS to broiler chicks through 42 days of age . Also, Awad et al. (2011b) reported that feeding diet contained $18 \%$ DDGS had no significant effect on carcass characteristics. 
Table 5. Effect of dietary DDGS and enzyme supplementation levels and their interaction on nutrient digestibility coefficients of NZW rabbits at 14 weeks of ages.

\begin{tabular}{|c|c|c|c|c|c|c|c|c|}
\hline \multirow{2}{*}{\multicolumn{2}{|c|}{$\begin{array}{l}\text { Treatment } \\
\text { groups }\end{array}$}} & \multicolumn{6}{|c|}{ Digestibility coefficient } & \multirow{2}{*}{$\frac{\text { Feeding value }}{\text { TDN }}$} \\
\hline & & DM & $\mathbf{O M}$ & $\mathbf{C P}$ & $\mathbf{E E}$ & $\mathbf{C F}$ & NFE & \\
\hline \multicolumn{9}{|c|}{ DDGS level \% } \\
\hline \multicolumn{2}{|l|}{0.0} & 65.42 & 67.54 & 75.46 & 74.47 & 57.46 & 66.77 & 58.72 \\
\hline \multicolumn{2}{|l|}{16.0} & 65.44 & 67.55 & 75.50 & 74.52 & 57.52 & 66.76 & 58.96 \\
\hline \multicolumn{2}{|l|}{22.0} & 66.05 & 67.78 & 76.07 & 74.60 & 57.58 & 66.92 & 59.25 \\
\hline \multicolumn{2}{|l|}{28.0} & 65.47 & 67.59 & 75.54 & 74.53 & 57.56 & 66.80 & 58.98 \\
\hline \multicolumn{2}{|l|}{ SEM } & 0.48 & 0.47 & 0.47 & 0.52 & 0.51 & 0.48 & 0.41 \\
\hline \multicolumn{2}{|c|}{ Significance } & $\mathbf{N S}$ & NS & $\mathbf{N S}$ & NS & NS & $\mathbf{N S}$ & $\mathbf{N S}$ \\
\hline \multicolumn{9}{|c|}{ Enzyme level (g / kg) } \\
\hline \multicolumn{2}{|l|}{0.0} & 65.58 & 67.59 & 75.63 & 74.51 & 57.51 & 66.78 & 58.95 \\
\hline \multicolumn{2}{|l|}{0.5} & 65.60 & 67.64 & 75.66 & 74.55 & 57.55 & 66.84 & 59.00 \\
\hline \multicolumn{2}{|l|}{ SEM } & 0.34 & 0.33 & 0.33 & 0.37 & 0.36 & 0.34 & 0.29 \\
\hline \multicolumn{2}{|c|}{ Significance } & NS & NS & $\mathbf{N S}$ & NS & NS & NS & NS \\
\hline \multicolumn{9}{|c|}{ Interactions } \\
\hline DDGS & \multicolumn{2}{|l|}{ EN } & & & & & & \\
\hline \multirow{2}{*}{0.0} & 0.0 & 65.41 & 67.53 & 75.45 & 74.45 & 57.45 & 66.77 & 58.71 \\
\hline & 0.5 & 65.42 & 67.55 & 75.46 & 74.48 & 57.47 & 66.76 & 58.73 \\
\hline \multirow{2}{*}{16.0} & 0.0 & 65.44 & 67.54 & 75.49 & 74.49 & 57.50 & 66.75 & 58.95 \\
\hline & 0.5 & 65.45 & 67.56 & 75.50 & 74.54 & 57.53 & 66.77 & 58.97 \\
\hline \multirow{2}{*}{22.0} & $\mathbf{0 . 0}$ & 66.03 & 67.72 & 76.05 & 74.59 & 57.54 & 66.84 & 59.20 \\
\hline & 0.5 & 66.06 & 67.83 & 76.10 & 74.61 & 57.61 & 66.99 & 59.30 \\
\hline \multirow{2}{*}{28.0} & 0.0 & 65.45 & 67.57 & 75.51 & 74.51 & 57.53 & 66.77 & 58.95 \\
\hline & 0.5 & 65.48 & 67.61 & 75.56 & 74.55 & 57.59 & 66.82 & 59.01 \\
\hline \multicolumn{2}{|l|}{ SEM } & 0.68 & 0.66 & 0.66 & 0.66 & 0.72 & 0.68 & 0.58 \\
\hline \multicolumn{2}{|c|}{\begin{tabular}{|l|} 
Significance \\
\end{tabular}} & NS & NS & $\mathbf{N S}$ & NS & NS & NS & NS \\
\hline
\end{tabular}

DDGS =Distillers dried grains with solubles, $\quad$ SEM $=$ Stander error mean NS $=$ Not significant. 
Table 6. Effect of dietary DDGS and enzyme levels and their interaction on carcass traits of NZW rabbits at 14 weeks of ages.

\begin{tabular}{|c|c|c|c|c|c|c|c|c|}
\hline \multicolumn{2}{|c|}{$\begin{array}{l}\text { Treatment } \\
\text { groups }\end{array}$} & $\begin{array}{c}\text { Fasted } \\
\text { LBW } \\
\text { (g) }\end{array}$ & $\begin{array}{c}\text { Evs. } \\
\text { Carcass } \\
\%\end{array}$ & $\begin{array}{c}\text { Head } \\
\%\end{array}$ & $\begin{array}{c}\text { Liver } \\
\%\end{array}$ & $\begin{array}{c}\text { Heart } \\
\%\end{array}$ & $\begin{array}{c}\text { T. edi. } \\
\text { parts } \\
\%\end{array}$ & $\underset{\%}{\text { Abd. Fat }}$ \\
\hline \multicolumn{9}{|c|}{ DDGS level \% } \\
\hline \multirow{2}{*}{\multicolumn{2}{|c|}{$\begin{array}{l}0.0 \\
16.0\end{array}$}} & 2153.3 & 50.76 & 5.48 & 3.81 & 0.33 & 60.38 & 0.67 \\
\hline & & 2004.2 & 49.42 & 5.50 & 3.53 & 0.30 & 60.75 & 0.65 \\
\hline \multirow{2}{*}{\multicolumn{2}{|c|}{$\begin{array}{l}22.0 \\
28.0\end{array}$}} & 2246.7 & 51.84 & 5.22 & 3.46 & 0.30 & 60.82 & 0.72 \\
\hline & & 2286.7 & 52.68 & 5.32 & 3.43 & 0.32 & 61.75 & 0.75 \\
\hline \multicolumn{2}{|l|}{ SEM } & 88.0 & 0.83 & 0.15 & 0.18 & 0.02 & 0.98 & 0.07 \\
\hline \multicolumn{2}{|c|}{ Significance } & NS & NS & NS & NS & NS & NS & NS \\
\hline \multicolumn{9}{|c|}{ Enzyme level (g/ kg) } \\
\hline \multirow{2}{*}{\multicolumn{2}{|c|}{$\begin{array}{l}0.0 \\
0.5\end{array}$}} & 2163.3 & 51.04 & 5.43 & 3.60 & 0.31 & 60.38 & 0.68 \\
\hline & & 2182.1 & 52.32 & 5.33 & 3.52 & 0.31 & 61.48 & 0.72 \\
\hline \multicolumn{2}{|l|}{ SEM } & 62.0 & 0.71 & 0.10 & 0.12 & 0.01 & 0.69 & 0.05 \\
\hline \multicolumn{2}{|c|}{ Significance } & NS & NS & NS & NS & NS & NS & $\mathbf{N S}$ \\
\hline \multicolumn{9}{|c|}{ Interactions } \\
\hline \multirow[t]{2}{*}{ DDGS } & EN & & & & & & & \\
\hline & 0.0 & 2228.3 & 50.68 & 5.46 & 3.46 & 0.33 & 59.93 & 0.68 \\
\hline 0.0 & 0.5 & 2078.3 & 50.86 & 5.50 & 4.15 & 0.32 & 60.83 & 0.67 \\
\hline \multirow{2}{*}{16.0} & 0.0 & 2005.0 & 50.99 & 5.57 & 3.60 & 0.30 & 60.17 & 0.63 \\
\hline & 0.5 & 2003.3 & 52.15 & 5.43 & 3.45 & 0.30 & 61.33 & 0.66 \\
\hline \multirow{2}{*}{22.0} & 0.0 & 2098.3 & 50.41 & 5.57 & 3.44 & 0.31 & 59.73 & 0.70 \\
\hline & 0.5 & 2395.0 & 52.27 & 5.87 & 3.47 & 0.29 & 61.90 & 0.76 \\
\hline \multirow{2}{*}{28.0} & 0.0 & 2321.7 & 52.42 & 5.10 & 3.88 & 0.30 & 61.70 & 0.72 \\
\hline & 0.5 & 2251.7 & 52.98 & 5.53 & 2.99 & 0.33 & 61.83 & 0.78 \\
\hline \multicolumn{2}{|l|}{ SEM } & 124.4 & 0.85 & 0.21 & 0.25 & 0.02 & 1.39 & 0.09 \\
\hline \multicolumn{2}{|c|}{ Significance } & NS & NS & NS & NS & NS & NS & NS \\
\hline
\end{tabular}

\section{Plasma metabolites}

Data of Table (7) indicated that All blood plasma constituents were not significantly affected by feeding DDGS diets except of total lipids which were significantly $(\mathrm{P}<0.01$ decreased. However, enzyme addition by $0.5 \mathrm{~g} / \mathrm{kg}$ diet resulted in significant increase of total lipids by $5.40 \%$ as compared with the control.

The enzyme supplementation had no significant effect on plasma total protein, total cholesterol, AST, ALT and creatinine, while, enzyme supplementation $(0.5 \mathrm{~g} / \mathrm{kg}$ diet $)$ resulted significant $(\mathrm{P}<0.01)$ increase of total lipids by $5.40 \%$ as compared to the control. The interaction effect between DDGS and enzyme supplementation on all blood constituents studied were not significant Table 7. 
Table 7. Effect of dietary DDGS and enzyme supplementation levels and their interaction on plasma constituents of NZW rabbits at 14 weeks of ages.

\begin{tabular}{|c|c|c|c|c|c|c|c|}
\hline \multicolumn{2}{|c|}{$\begin{array}{l}\text { Treatment } \\
\text { groups }\end{array}$} & $\begin{array}{c}\text { Total } \\
\text { protein } \\
(\mathrm{g} / \mathrm{dl})\end{array}$ & $\begin{array}{c}\text { Total } \\
\text { Lipids } \\
\text { (g/dl) }\end{array}$ & $\begin{array}{c}\text { Total } \\
\text { cholester } \\
\text { ol }(\mathrm{mg} / \mathrm{dl})\end{array}$ & $\begin{array}{c}\text { AST } \\
\text { (U/dl) }\end{array}$ & $\begin{array}{c}\text { ALT } \\
\text { (U/dl) }\end{array}$ & $\begin{array}{c}\text { Creatini } \\
\text { n } \\
(\mathrm{mg} / \mathrm{dl})\end{array}$ \\
\hline \multicolumn{8}{|c|}{ DDGS level \% } \\
\hline \multicolumn{2}{|l|}{0.0} & 6.38 & $3.24^{\mathrm{a}}$ & 84.22 & 16.35 & 19.02 & 0.86 \\
\hline \multicolumn{2}{|l|}{16.0} & 6.52 & $3.06^{\mathrm{b}}$ & 85.10 & 17.60 & 20.27 & 0.90 \\
\hline \multicolumn{2}{|l|}{22.0} & 6.52 & $2.94^{b}$ & 79.67 & 18.48 & 21.16 & 0.92 \\
\hline \multicolumn{2}{|l|}{28.0} & 6.49 & $2.92^{b}$ & 80.88 & 19.23 & 21.90 & 0.89 \\
\hline \multicolumn{2}{|l|}{ SEM } & 0.08 & 0.05 & 2.46 & 0.89 & 0.88 & 0.03 \\
\hline \multicolumn{2}{|c|}{ Significance } & NS & $* *$ & NS & NS & NS & NS \\
\hline \multicolumn{8}{|c|}{ Enzyme level (g / kg) } \\
\hline \multicolumn{2}{|l|}{\begin{tabular}{|l|}
0.0 \\
\end{tabular}} & 6.46 & $2.96^{b}$ & 84.03 & 18.07 & 20.65 & 0.89 \\
\hline \multicolumn{2}{|l|}{\begin{tabular}{|l|}
0.5 \\
\end{tabular}} & 6.48 & $3.12^{\mathrm{a}}$ & 81.40 & 17.77 & 20.52 & 0.89 \\
\hline \multicolumn{2}{|l|}{\begin{tabular}{|l|} 
SEM \\
\end{tabular}} & 0.06 & 0.03 & 1.74 & 0.63 & 0.62 & 0.02 \\
\hline \multicolumn{2}{|c|}{$\begin{array}{l}\text { Significance } \\
\end{array}$} & $\mathbf{N S}$ & $* *$ & $\mathbf{N S}$ & $\mathbf{N S}$ & $\mathbf{N S}$ & $\mathbf{N S}$ \\
\hline \multicolumn{8}{|c|}{ Interactions } \\
\hline \multirow{2}{*}{ DDGS } & $\mathbf{E N}$ & & & & & & \\
\hline & 0.0 & 6.38 & 3.14 & 88.10 & 16.40 & 18.73 & 0.88 \\
\hline 0.0 & 0.5 & 6.39 & 3.34 & 80.33 & 16.30 & 19.30 & 0.84 \\
\hline \multirow{2}{*}{16.0} & 0.0 & 6.44 & 3.02 & 84.07 & 17.87 & 20.53 & 0.87 \\
\hline & 0.5 & 6.61 & 3.09 & 86.13 & 17.33 & 20.00 & 0.92 \\
\hline \multirow{2}{*}{22.0} & 0.0 & 6.45 & 2.87 & 82.20 & 18.57 & 21.23 & 0.90 \\
\hline & 0.5 & 6.59 & 3.01 & 75.13 & 18.40 & 21.08 & 0.92 \\
\hline \multirow{2}{*}{28.0} & 0.0 & 6.44 & 2.81 & 81.77 & 19.43 & 22.10 & 0.91 \\
\hline & 0.5 & 6.54 & 3.03 & 84.00 & 19.03 & 21.70 & 0.87 \\
\hline \multicolumn{2}{|l|}{ SEM } & 0.11 & 0.06 & 3.47 & 1.27 & 1.25 & 0.05 \\
\hline \multicolumn{2}{|c|}{ Significance } & NS & NS & NS & NS & NS & NS \\
\hline
\end{tabular}

SEM = Satander error mean

a,b :Means in the same column bearing different superscript are significantly different $(\mathrm{P} \leq 0.05)$.

NS = Not significant, $\quad * *=$ Significant at $(0.01)$.

The present results are in agreement with those obtained by Gaber et al. (2008) who reported that rabbits fed diet contained different levels of DDGS and enzyme addition had no significant effects on plasma total protein , total cholesterol, AST and ALT, whereas total lipids were significantly decreased at 8-14 wks of age. Shalash et al. (2009) reported that plasma cholesterol and creatinine content of laying hens were not significantly affected by feeding diet contained $12 \%$ DDGS as compared to the control. Also, Awad et al. (2011 b) found that total protein, triglycerides, total cholesterol, AST, ALT and 
creatinine content were not significantly affected by feeding diets contained 6 , 12 and $18 \%$ DDGS in ducklings diets as compared to the control.

In conclusion, from the economical points of view, it could be concluded that the DDGS could be used successfully up to $28 \%$ in feeding growing rabbits without any adverse effects on growth performance, carcass traits, blood constituents and animal health in general.

\section{REFERENCES}

AOAC (1995). Association of Analytical Chemists. Official Methods of Analysis. $16^{\text {thed }}$. Washington, D.C., U.S.A.Archibeqe, S. L; H. C.

Freetly and C. L. Ferrell (2008). Feeding distillers grains supplements to improve amino acids nutritive of lambs consuming moderate-quality forages. Journal of Animal Science, 86 : 691-701.

Awad, A. L., M.A.A. Hussein , A.I.A. Ghonim and M.G. Kasim (2011 a). Effect of dietary inclusion level of distillers dried grains with solubles (DDGS) on laying performance in Domyati ducks. Egyptian Poultry Science, 31: 51-63

Awad, A. L., M.A.A. Hussein , A.I.A. Ghonim and M.G. Kasim (2011 b). Effect of dietary inclusion of distillers dried grains with solubles (DDGS) on growth performance of Domyati ducklings. Egyptian Poultry Science, 31:65-75

Batal, A. and N. Dale (2003). Mineral composition of distillers dried grains with solubles. J. Appl. Poult. Res., 12: 400-403.

Bucolo, G. , and H. David (1973). Quantitative determination of serum triglycerides by the use of the enzyme. Clin. Chem., 19:475.

Couch, J. R., J. H. Trammell, A. Tolan and W. W. Abbott (1970). Corn distillers dried grains with solubles in low lysine diets for rearing broiler breeder replacement pullets. Proc. Distillers Res. Council, 25: 25-33. Cincinnati, $\mathrm{OH}$.

Cheeke, P. R; N. M. Patton and G. S. Tempelton (1982). Rabbit Production. $5^{\text {th }}$ Ed. Int. Print, and Pubi., Danville 11.

Duncan, D. B. (1955). Multiple range and multiple $\mathrm{F}$ tests. Biometrics, 11:1-42.

Ellefson, R. D., and W. T. Caraway (1976). fundamental of Clinical Chemistry. Ed Tietz N.W., 506 pp.

Fekete, S. and T. Gippert (1982). Multiple range and multiple F-test. Biometrics, 11 : 3 - 42.

Gabr, A. A. , Kh. El. Sherif and A. F. Naeem (2008). Effect of inclusion dried distillers grains with solubles with enzyme addition in rabbit diets on performance, digestibility ,carcass traits and some blood constituents. J. Agric. Sci. Mansoura Univ.,33: 6335 - 6349. 
Hill, J. (2002). Effect of level of inclusion and method of presentation of a single distillery by-product on the processes of ingestion of concentrate feeds by horses. Livestock Prod. Sci., 75: 209 -218.

Kleinschmit, D. H. ; D. J. Schingoethe ; K. F. Kalscheur and A. R. Hippen (2006). Evaluation of various sources of corn dried distillers grains plus solubles for lactating dairy cattle. J. Dairy Sci.,89: $4784-4794$.

Jensen, L. S. (1981). Value of distillers dried grains with solubles in poultry feeds. Proc. Distillers Research Conf., 36: 87-93. Cincinnati OH.

Lumpkins, B. S., A. B. Batal and N. M. Dale(2004). Evaluation of distillers dried grains with solubles as a feed ingredient for broilers. Poultry Science, 83: 1891-1896.

MacDonald, J. C. ;T. J. Klopfenstein ; G. E. Erickson and W.A. Griffin (2007). Effects of dried distillers grains and equivalent undegradable intake protein or ether extract on performance and forage intake of heifers grazing smooth brome grass pastures. Journal of Animal Science, 85: 2614-2624.

Marten, J. L.; A. S. Cupp ; R. J. Rasby ; Z. C. Hall and R. N. Funston (2007). Utilization of dried distillers grains for developing beef heifers. J. Anim. Sci., 85:2298-2303.

Noll, S. L. and J. Brannon (2006). Inclusion levels of corn distillers grains with solubles and poultry byproduct meal in market turkey diets. Poultry Science, 85 (Suppl. 1): 106-107.

Noll, S. E., C. M. Parsons, and W. A. Dozier (2007). Formulating poultry diets with DDGS-How far can we go. Proceedings $5^{\text {th }}$ Mid Atl. Nutr. Conf. , N. G. Zimmerman, ed., Univ. Maryland, College Park.

North, O. M. (1981). Commercial Chicken Production Manual. $2^{\text {th }}$ Ed. AVI Publishing Company, Inc., Westpor, Connecticut.

NRC (1977). National research council, nutrient requirements of Domestic Animals. Nutrition Requirement of Rabbits. Washington, D. C.,USA.

Peters, T. (1968). Determination of total protein in serum. Clinical Chemistry, 14:1147.

Reitman, S., and S. Frankel (1957). Coloric determination of GOT or GPT activity. Am. J. Clin. Path., 28-56.

Robertson, K. D. (2003). Use of dried distillers grain with solubles in growing-finishing diets of turkey hens. International Journal Of Poultry Science, 2: 389-393.

SAS (2004). SAS User's Guide: Statistics, 2004. Edition 9.1 . SAS Institute Inc., Cary, NC.

Shalash, S. M. M., M. N. Ali, M. A. M. Sayed, Hoda E. El-Gabry and M. Shabaan (2009). Novel method for improving the utilization of corn dried distillers grains with solubles in broiler diets. International Journal Of Poultry Science, 8: 545-552. 
Shalash, S. M., S. Abou El-Wafa, R. A. Hassan, Nehad A. Ramadan, Manal S. Mohamed and Hoda E. El-Gabry (2010). Evaluation of distillers dried grains with solubles as feed ingredient in laying hen diets. International Journal Of Poultry Science, 9 : 537-545

Shurson, J. (2008). Distiller grain by-products in livestock and poultry feeds. July 29 www.ddgs.umn.edu/profiles.htm

Thacker, P.A. and G.P. Widyaratne (2007). Nutritional value of diets containing graded levels of wheat distillers grains with solubles fed to broiler chicks. Journal of the Science of Food Agriculture, 87: 13861390.

Waldroup, P.W., J.A. Owen, B.E. Ramsey and D.L. Whelchel (1981). The use of high levels of distillers dried grains plus solubles in broiler diets. Poultry Science, 60: 1479-1484.

Wang, Z., S. Cerrate,C. Coto, F. Yan and P.W. Waldroup (2007). Utilization of distiller dried grains with solubles (DDGS) in broiler diet using a standardized nutrient Matrix. International Journal of Poultry Science, 6: 470-477.

Windhorst, H.W. (2007). Bio energy production, a threat to the global egg industry. World Poultry Science J., 63: 365-379.

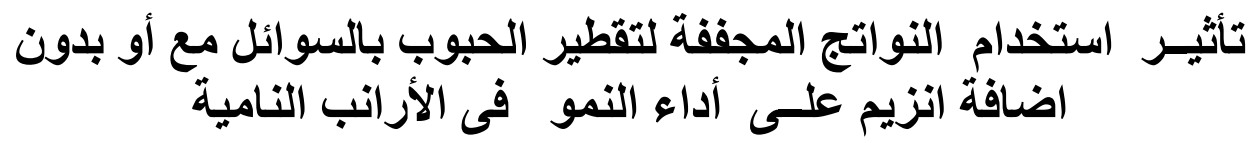

$$
\begin{aligned}
& \text { مجدي أحمد عوض حسين ، عادل السيد محمد ابراهيم الدسوقى الزئي }
\end{aligned}
$$

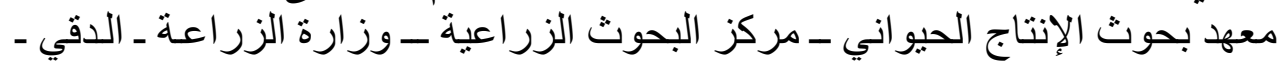

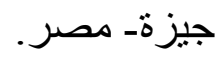

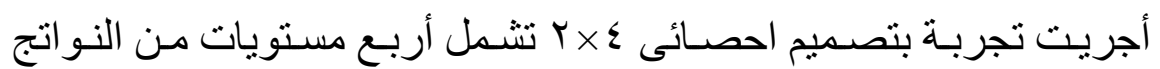

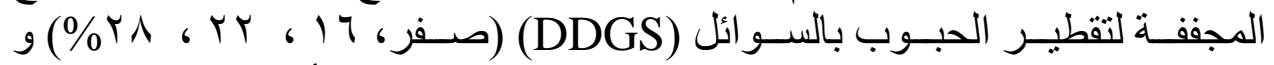

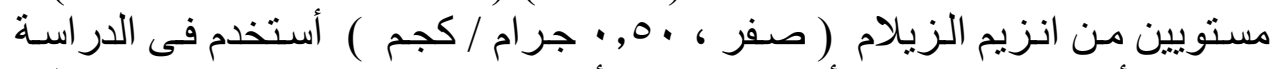

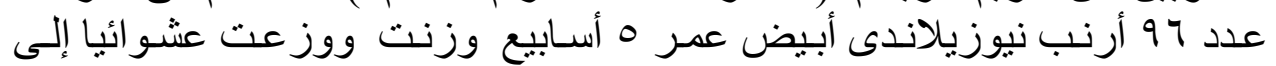

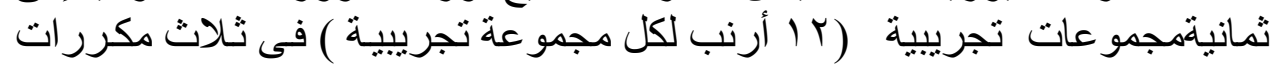

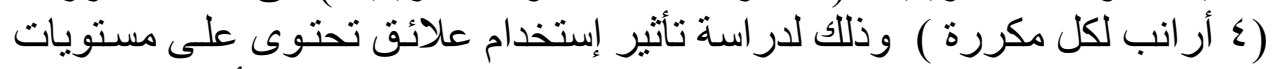

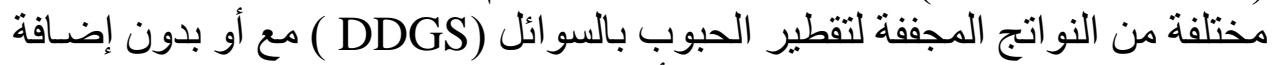

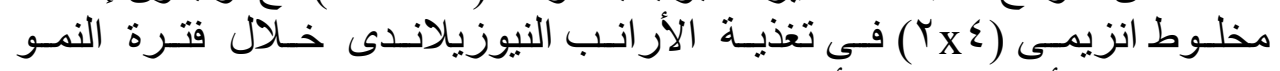

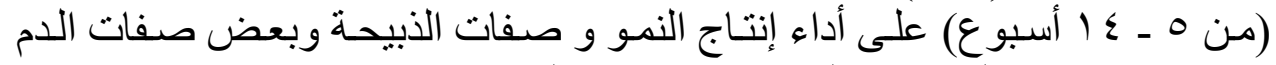

$$
\begin{aligned}
& \text { ومعاملات هضم المركبات الغذائية فضلا عن الكفاءة الاقتصادية. }
\end{aligned}
$$


وبتحليل النتائج اتضح الآتي:

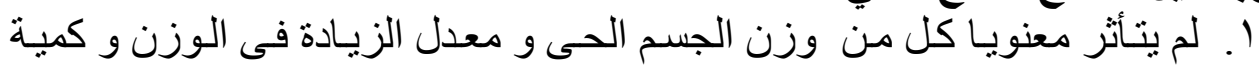

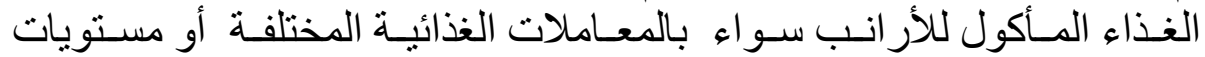

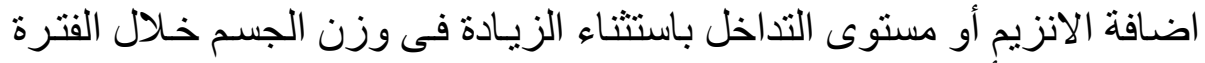

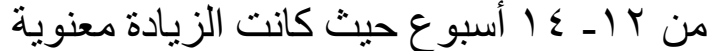

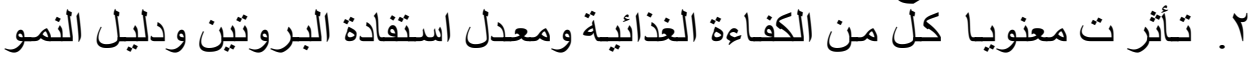

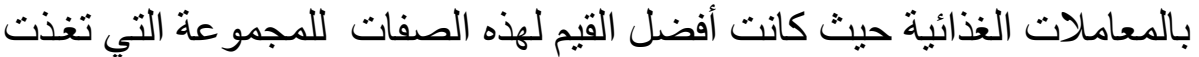

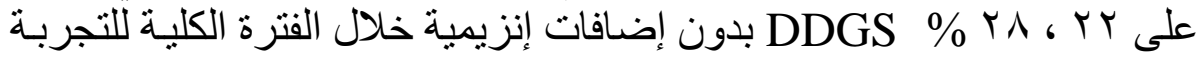
بينما انخفضت معنويا قيمة كفاءة تحويل الطاقة بزياد مستوى

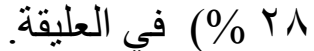

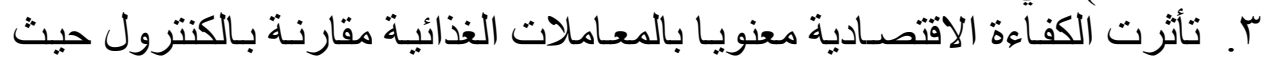

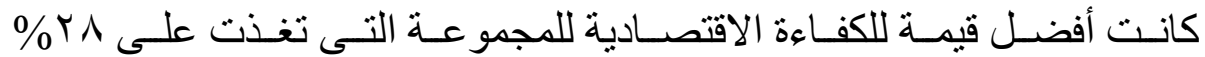
بدون اضافات انزيمية خلال الفترة الكلية للتجربة. DDGS

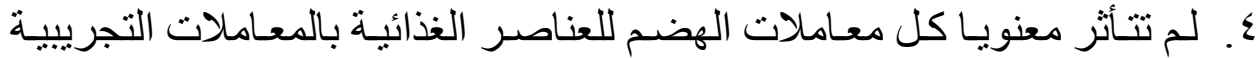

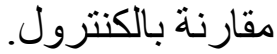

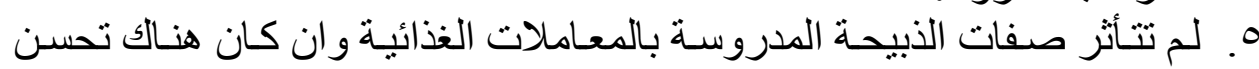

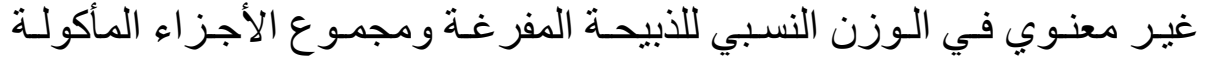

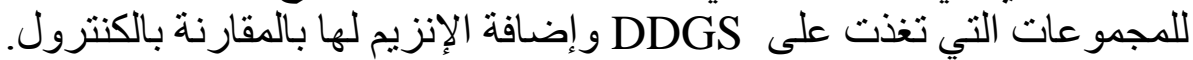

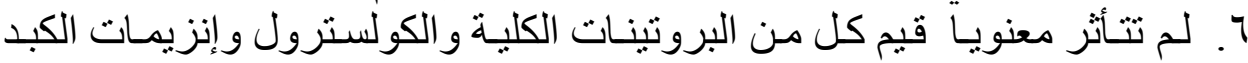

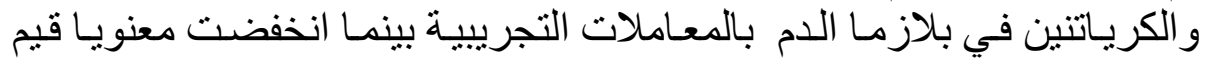
الليبيدات الكلية بالتغذيـة على

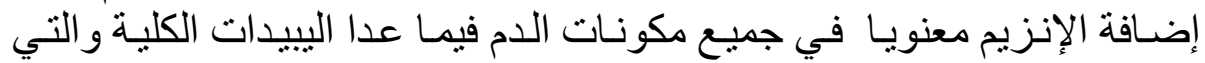

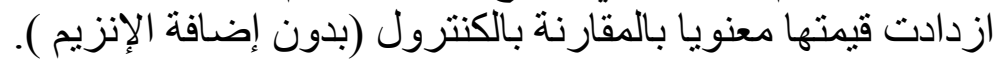

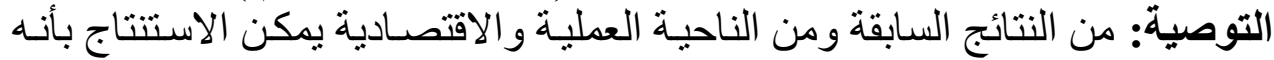

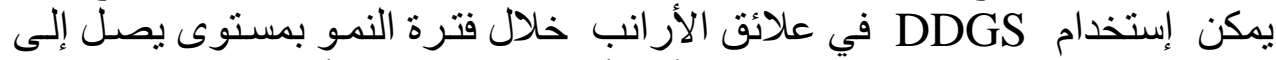

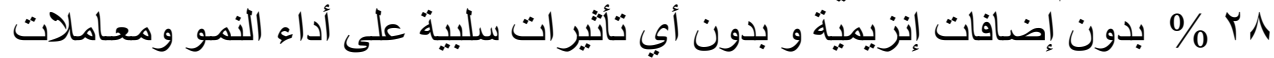

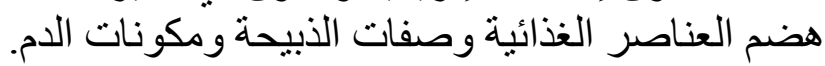

